\title{
KEEFEKTIFAN PERAN KEPALA SEKOLAH DALAM MENINGKATKAN KINERJA GURU
}

\author{
Muhamad Sholeh \\ Mahasiswa S-3 Manajemen Pendidikan \\ Universitas Negeri Jakarta \\ e-mail : muhamadsoleh27@yahoo.co.id
}

\begin{abstract}
Abstrak
Peran kepemimpinan kepala sekolah dalam organisasi sekolah sangat penting karena peran strategis kepala sekolah ikut mempengaruhi kinerja guru dalam pelaksanaan kegiatan Proses Belajar Mengajar (PBM). Sebagai pemimpinan pendidikan, kepala sekolah memiliki tugas dan tanggungjawab yang cukup berat. Keefektifan kepala sekolah dalam menerapkan fungsi-fungsi manajemen adalah ketepatan penerapan kemampuan kepala sekolah dalam melakukan perencanaan, pengorganisasian, penggerakan dan pengendalian serta pendayagunaan seluruh sumbersumber pendidikan baik ketenagaan, dana, sarana dan prasarana termasuk informasi secara optimal, yaitu menunjukkan sejauh mana kepala sekolah melaksanakan tugas pokoknya secara baik dan benar untuk mencapai tujuan. Kinerja guru sangat terkait dengan efektifitas guru dalam melaksanakan fungsinya. Keefektifan guru dalam melaksanakan fungsinya, adalah guru yang efektif; 1) memiliki pribadi kooperatif, daya tarik penampilan, minat besar, pertimbangan dan kepemimpinan, 2) menguasai metode mengajar yang baik, 3) memiliki tingkah laku yang baik saat mengajar, 4) menguasai berbagai kompetensi dalam mengajar.
\end{abstract}

\section{Kata Kunci : Keefektifan, Kepala Sekolah, Kinerja Guru}

\section{PENDAHULUAN}

Krisis ekonomi, politik dan kepercayaan yang berkepanjangan yang melanda bangsa indonesia telah membawa dampak hampir kepada seluruh aspek dan tatanan kehidupan. Walaupun banyak menimbulkan keterpurukan bagi bangsa dan rakyat, salah satu hikmah positif yang muncul adalah timbulnya pemikiran dasar yang menumbuhkan reformasi di berbagai aspek kehidupan berbangsa dan bernegara. Fokus utama reformasi ini adalah untuk menciptakan masyarakat yang madani dalam kehidupan pemerintahan, bermasyarakat dan bernegara yang memiliki nilainilai "Good Governance" yang menuntun nilai demokrasi dan sikap keterbukaan, kejujuran, keadilan, berorientasi pada kepentingan rakyat, serta bertanggung jawab (accountable) kepada rakyat (Koswara, 2000).

Keinginan bersama untuk melaksanakan reformasi dalam kehidupan berbangsa dan bernegara di bidang pendidikan lebih nampak lagi dengan dikeluarkannya Undang-Undang Nomor 20 Tahun 2003 Tentang Sistem Pendidikan Nasional (Sisdiknas). Adapun substansi dari undang-undang sisdiknas yang baru tersebut nampak dari visinya: terwujudnya sistem pendidikan sebagai pranata sosial yang kuat dan berwibawa untuk memberdayakan semua warga negara Indonesia berkembang menjadi manusia yang berkualitas sehingga mampu proaktif menjawab tantangan zaman. Salah satu upaya meningkatkan mutu pendidikan yang ada adalah melakukan pemberdayaan keefektifan peran strategis kepala sekolah.

Agar mutu pendidikan bukan lagi menjadi fatamorgana di padang pasir dan bukan menjadi alat legitimasi politik, apalagi sebagai alat pengungkit (everage) pecitraan dari golongan tertentu maka seluruh steakholders terus tingkatkan perannya dalam peningkatan mutu pendidikan. Peran strategis kepala sekolah dalam pemeranan keefektifan kepala sekolah untuk menjalankan fungsi-fungsi manajemen dan kinerja guru perlu ditingkatkan agar tercapai mutu pendidikan.

Kepemimpinan pendidikan memerlukan perhatian yang utama karena melalui kepemimpinan yang baik kita harapkan lahir tenaga-tenaga yang berkualitas dalam berbagai bidang sebagai pemikir, perencana dan pekerja yang handal. Melalui pendidikan kita menyiapkan tenaga-tenaga yang berkualitas, tenaga yang siap latih dan siap pakai, memenuhi kebutuhan 
masyarakat bisnis dan industri serta masyarakat lainnya.

Dalam undang-undang ri nomor 20 tahun 2003 tentang sistem pendidikan nasional dijelaskan: tujuan dan fungsi pendidikan nasional adalah untuk mengembangkan kemampuan dan membentuk watak serta peradaban bangsa yang bermartabat dalam rangka mencerdaskan kehidupan bangsa, bertujuan untuk berkembangnya potensi peserta didik agar menjadi manusia yang beriman dan bertaqwa kepada tuhan yang maha esa, berakhlak mulia, sehat, berilmu, cakap kreatif, mandiri dan menjadi warga negara yang demokratis serta bertanggung jawab.

Peningkatan mutu pendidikan merupakan sasaran pembangunan di bidang pendidikan nasional dan merupakan bagian integral dari upaya peningkatan kualitas manusia indonesia secara menyeluruh. Upaya mencerdaskan kehidupan bangsa menjadi tanggung jawab pendidikan terutama dalam mempersiapkan peserta didik menjadi subjek yang bertaqwa kepada tuhan yang maha esa, berakhlak mulia, tangguh, kreatif, mandiri, demokratis dan professional di bidangnya masing-masing.

Dalam rangka mewujudkan fungsi dan tujuan pendidikan nasional seperti di atas selain perlu adanya tenaga guru yang profesional, kepemimpinan merupakan hal yang sangat penting dalam keberhasilan organisasi sekolah. Perilaku kepemimpinan kepala sekolah harus mendorong kinerja para guru dengan menunjukkan rasa bersahabat, dekat dengan penuh pertimbangan terhadap guru, baik secara individu maupun secara kelompok (Mulyasa, 2000).

Selaku manajer, pemimpin, administrator, dan supervisor kepala sekolah mempunyai tanggung jawab penting dalam mengembangkan semua potensi dan sumber pendidikan yang terdapat di sekolah. Kepala sekolah harus mampu dan berupaya untuk mempergunakan semua sumber daya dan potensi seefisien dan seefektif mungkin guna pencapaian tujuan pendidikan yang telah ditetapkan. Oleh karena itu, kepemimpinan kepala sekolah yang mempunyai arti penting dalam proses pendidikan harus mampu mengelola dan memanfaatkan semua sumber daya yang ada di sekolah sehingga tercapai keefektifan pelaksanaan
Proses Belajar Mengajar (PBM) di sekolah yang dapat melahirkan perubahan kepada anak didik.

Kepala sekolah memiliki kekuasaan yang lebih besar untuk mengambil keputusan yang berkaitan dengan kebijakan pendidikan di tingkat sekolah. Kekuasaan lebih besar yang dimiliki oleh kepala sekolah dalam pembuatan keputusan perlu dilaksanakan secara demokratis, antara lain dengan melibatkan semua pihak khususnya guru dan orang tua peserta didik, membuat keputusan dalam hal-hal yang relevan dengan tugasnya serta menjalin kerjasama dengan masyarakat dalam upaya peningkatan mutu pendidikan.

Keberhasilan kepala sekolah dalam mengelola Proses Pembelajaran (PBM) di sekolahnya akan sangat tergantung pada keefektifan kepemimpinan kepala sekolah. Itulah sebabnya timbul suatu ungkapan bahwa sekolah yang baik adalah hasil kerja keras seorang kepala sekolah yang efektif. Sekolah yang efektif, bermutu dan favorit tidak lepas dari peran kepala sekolahnya. Pada umumnya sekolah yang efektif dan bermutu dipimpin oleh seorang kepala sekolah yang memiliki kemampuan dalam menerapkan fungsifungsi manajemen, memiliki wawasan, pengetahuan dan kemampuan analisis serta mempunyai jiwa kepemimpinan, disiplin dan memiliki semangat kerja yang tinggi.

Keberhasilan suatu organisasi, termasuk organisasi sekolah dalam mencapai tujuannya sangat dipengaruhi aspek manajemen. Manajemen pada hakekatnya merupakan suatu proses merencanakan, mengorganisasikan melaksanakan, memimpin dan mengendalikan usaha para anggota organisasi serta mendayagunakan seluruh sumbersumber daya organisasi dalam rangka mencapai tujuan - tujuan yang telah ditetapkan. Ini berarti organisasi sekolah sangat memerlukan keberadaan manajemen untuk mencapai tujuan sekolah. Tilaar (2001) mengemukakan pendapatnya bahwa masalah manajemen pendidikan merupakan salah satu pokok persoalan yang menimbulkan krisis dalam dunia pendidikan dewasa ini.

Tidak dapat dipungkiri bahwa tidak semua kepala sekolah dapat menjalankan perannya sebagai manajer, leader, supervisor, dan administrator. Banyak kepala sekolah yang mengabaikan peran yang sesungguhnya sehingga sekolah yang dipimpinnya timbul berbagai macam masalah dan gejola di lingkungan kerjanya. Hal ini disebabkan karena kepala sekolah tidak dapat berprilaku sesuai dengan perannya dan tidak memiliki pengetahuan 
kepemimpinan serta tidak memiliki kemampuan untuk menerapkan fungsi-fungsi manajemen.

Dalam upaya pencapaian tujuan sekolah, seorang kepala sekolah dituntut memiliki kemampuan untuk menerapkan fungsi-fungsi manajemen secara efektif agar mampu mendayagunakan seluruh sumber daya baik sumber daya manusia maupun sumber daya non manusia demi tercapainya tujuan yang telah ditetapkan.

Kepala sekolah memegang peranan dan tanggung jawab sebagai administrator, manajer, supervisor, dan leader pendidikan, yang harus memiliki kompetensi professional. Kepala sekolah harus memiliki kemampuan untuk menerapkan fungsi-fungsi manajemen yakni kemampuan melaksanakan proses perencanaan, pengorganisasian, penggerakan, dan pengendalian serta mampu mendayagunakan seluruh sumber daya yang dimiliki sekolah agar keberhasilan dan keefektifan pelaksanaan Proses Pembelajaran (PBM) dapat tercapai. Kepala sekolah yang profesional mampu untuk menetapkan tujuan pendidikan, menaksir kebutuhan personil, mengidentifikasi bidang-bidang masalah dan merancang pemecahan yang efektif, serta menyusun anggaran dan penggunaan sumbersumber pendidikan secara efisien dan efektif. Sesuai dengan peran dan tugas-tugas di atas, kepala sekolah merupakan manajer sekolah, pemimpin sekolah, administrator sekolah, dan supervisor sekolah dituntut untuk dapat menciptakan manajemen sekolah yang efektif.

$\begin{array}{ccc}\text { Menurut } & \text { Mantja } & \text { (2000), keefektifan } \\ \text { manajemen pendidikan ditentukan oleh }\end{array}$
profesionalisme manajer pendidikan. Kehadiran manajer pendidikan yang memiliki kemampuan manajemen merupakan faktor yang sangat penting agar dapat mengelola semua sumber daya yang ada di sekolah baik ketenagaan, dana, sarana dana prasarana juga termasuk informasi.

Berdasarkan uraian di atas, kepala sekolah yang didukung dengan kemampuannya dalam menerapkan fungsi-fungsi manajemen akan mampu berbuat secara maksimal sesuai dengan kewenangan dan tanggung jawabnya dalam merencanakan, mengorganisasikan, menggerakkan dan mengendalikan pelaksanaan Kegiatan Belajar Mengajar (PBM) di sekolah agar dapat mencapai tujuan yang telah ditetapkan. Untuk itu, penelitian ini lebih difokuskan pada kemampuan kepala sekolah dalam menerapkan fungsi-fungsi manajemen pada pelaksanaan proses pembelajaran.

\section{KEEFEKTIFAN PERAN KEPALA SEKOLAH}

\section{Pengertian Keefektifan}

Ada beberapa pendapat para ahli yang dapat dijadikan sebagai rujukan. Sagala (2005) mengutip] beberapa pendapat para ahli antara lain: Etzioni (1964) mengemukakan bahwa; keefektifan adalah derajat sebuah organisasi dalam mencapai tujuannya. Steer (1975) mengatakan bahwa keefektifan organisasi menekankan perhatian pad; kesesuaian hasil yang dicapai organisasi dengan tujuan yang akan dicapai Dai Tobert (1987) berpendapat bahwa keefektifan organisasi adalah kesesuaian hasi yang dicapai organisasi dengan tujuannya.

Dari beberapa pendapat para ahli tersebut di atas dapat dipahami bahwa; keefektifan berkaitan dengan kesesuaian antara tugas pokok, aspek-aspek prilaku dan hasil yang ingin dicapai. Apabila dihubungkan dengan peran kepala sekolah maka keefektifan berarti kemampuan kepala sekolah dalam mengelola sumber daya secara optimal, yaitu menunjukkan sejauh mana kepala sekolah melaksanakan tugas pokoknya secara baik dan benar untuk mencapai tujuan.

Bertolak dari tiga pendapat pakar tersebut di atas maka setiap organisasi apapun bentuk organisasinya termasuk organisasi pendidikan harus mampi mengkoordinasikan semua pekerjaan/aktivitas agar pekerjaan itu menjadi efektif dalam mencapai tujuan organisasi. Pidarta (2004) mengatakan bahwa suatu pekerjaan dikatakan efektif apabila pekerjaan itu memberikan hasil yang sesuai

Dengan kriteria yang ditetapkan semula, atau pekerjaan itu sudah mampu merealisir tujuan organisasi dalam aspek yang dikerjakan.

Sekolah adalah termasuk sebuah organisasi yang didalamnya terdapat berbagai macam pekerjaan atau aktivitas yang perlu diatur atau dikoordinasikan agar semua pekerjaan lebih terarah dalam mencapai 
tujuan. Orang yang mengatur dan mengkoordinasikan semua pekerjaan di sekolah adalah kepala sekolah. Kepala sekolah, guru, dan pegawai lain saling memberikan pengaruh positif dalam upaya memajukan dan mengembangkan sekolah. Sagala (2005) mengatakan keefektifan sekolah mempengaruhi dan dipengaruhi oleh aspek-aspek prilaku organisasi yang terdiri dari kepala sekolah, guru, siswa dan personel sekolah lainnya. Kepala sekolah, guru, dan setiap personel sekolah menempati posisi dan peranan yang penting dalam memikul tanggung jawab untuk mengembangkan dan memajukan setiap sub sistem masing-masing secara keseluruhan.

Manajer/kepala sekolah pada prinsipnya harus mampu untuk meningkatkan dan memelihara kinerja individu, kelompok, dan organisasi. Untuk itu sudah sewajarnya manajer/kepala sekolah dapat meningkatkan dan memelihara keefektifan individu, keefektifan kelompok dan keefektifan organisasi. Keefektifan individu merupakan tingkat yang paling dasar yang menekankan pada pelaksanaan tugas/pekerjaan dari anggota organisasi. Kepala sekolah/manajer dapat mengetahui keefektifan individu melalui proses evaluasi kinerja secara rutin yang nantinya dapat dijadikan dasar bagi promosi, kenaikan gaji atau jabatan. Keefektifan kelompok adalah kontribusi dari keefektifan

Individu yang menjadikan hasil kinerja kelompok, karena umumnya individu bekerja dalam kelompokkelompok. Keefektifan organisasi merupakan akumulasi dari keefektifan individu dan keefektifan kelompok.

Keefektifan sering juga diartikan sebagai ketepatan sasaran dari suatu proses yang berlangsung untuk mencapai tujuan yang telah ditetapkan sebelumnya. Maka yang dimaksud dengan keefektifan kepala sekolah adalah ketepatan kepala sekolah dalam menjalankan perannya dalam proses pengelolaan sumber-sumber pendidikan baik ketenagaan, dana, sarana dan prasarana termasuk informasi dalam mencapai tujuan yang telah ditetapkan.

Ada tiga variable yang menentukan keefektifan menurut Fred E. Fiedler (dalam Purwanto, 2003) yaitu: (1) hubungan antara pemimpin dengan pimpinan, (2) derajat struktur tugas,(3) kekuasaan pimpinan. Pendapat ini memberikan gambaran bahwa keefektifan dibutuhkan untuk,(l) mencapai tujuan apapun yang hendak dirumuskan oleh sebuah organisasi, (2) menjaga keseimbangan antara kepentingan dan tujuan masing-masing personel yang sering bertentangan, (3) mencapai efektivitas dan efisiensi.

Scheerens dan Creemers (1991) menggunakan dua istilah keefektifan yaitu keefektifan pengajaran dan keefektifan manajemen. Keefektifan pengajaran dimaksudkan untuk menunjukkan keefektifan pendidikan pada tingkat kegiatan kelas dan keefektifan manajemen pada tingkat pengelolaan sumber-sumber pendidikan dalam hal ini ketenagaan, dana, sarana dan prasarana termasuk informasi.

Peter Drucker (1964) mengartikan keefektifan sebagai doing the right thing atau melakukan pekerjaan yang benar. Sementara Handoko (1999) mengartikan keefektifan sebagai kemampuan memiliki cara yang tepat dalam menyelesaikan pekerjaan. Dari dua pendapat pakar ini dapat dipahami bahwa keefektifan merupakan ketepatan sasaran dari suatu proses yang berlangsung dengan memanfaatkan semua potensi sumber daya yang ada untuk mencapai tujuan yang telah ditentukan sebelumnya.

Berdasarkan pendapat para pakar tersebut di atas dapat disimpulkan bahwa keefektifan kepala sekolah adalah ketepatan penerapan peran strategis kepala sekolah dalam pendayagunaan seluruh sumber-sumber pendidikan baik ketenagaan, dana, sarana dan prasarana termasuk informasi secara optimal, yaitu menunjukkan sejauh mana kepala sekolah 
melaksanakan tugas pokoknya secara baik dan benar untuk mencapai tujuan.

\section{Keefektifan Organisasi Sekolah}

Secara teoritis organisasi sekolah dalam menyelenggarakan programnya terlebih dahulu menyusun tujuan dengan baik yang penerapannya dilakukan secara efektif dan efisien dalam Proses Belajar Mengajar (PBM). Keefektifan organisasi sekolah tergantung pada rancangan organisasi dan pelaksanaan fungsi komponen organisasi yang meliputi proses pengelolaan informasi, partisipasi, pelaksanaan tugas pokok organisasi, perencanaan, pengorganisasian, penggerakan dan pengendalian.

Di antara pemimpin pendidikan yang bermacam-macam jenis dan tingkatannya, kepala sekolah merupakan pemimpin pendidikan yang sangat penting karena kepala sekolah berhubungan langsung dengan pelaksanaan program pendidikan di sekolah. Ketercapaian tujuan pendidikan sangat bergantung pada kecakapan dan kebijaksanaan kepala sekolah sebagai salah satu pemimpin pendidikan. Hal ini karena kepala sekolah merupakan seorang pejabat yang profesional dalam organisasi sekolah yang bertugas mengatur semua sumber organisasi dan bekerjasama dengan guru-guru dalam mendidik siswa untuk mencapai tujuan pendidikan.

Kegiatan lembaga pendidikan sekolah di samping diatur oleh pemerintah, sesungguhnya sebagian besar ditentukan oleh aktivitas kepala sekolahnya. Menurut Pidarta (1990), kepala sekolah merupakan kunci kesuksesan sekolah dalam mengadakan perubahan. Sehingga kegiatan meningkatkan dan memperbaiki program dan proses pembelajaran di sekolah sebagian besar terletak pada diri kepala sekolah itu sendiri. Pidarta (1997) menyatakan bahwa kepala sekolah memiliki peran dan tanggungjawab sebagai manajer pendidikan, pemimpin pendidikan, administrator pendidikan, dan supervisor pendidikan.

\section{a) Manager Sekolah}

Kepala sekolah sebagai manajer di sekolah. Tugas manajer pendidikan adalah merencanakan sesuatu atau mencari strategi yang terbaik, mengorganisasi dan mengkoordinasi sumber-sumber pendidikan yang masih berserakan agar menyatu dalam melaksanakan pendidikan, dan mengadakan kontrol terhadap pelaksanaan dan hasil pendidikan. Kepala sekolah memiliki kewenangan dalam mengambil keputusan, karena atas perannya sebagai manajer di sekolah dituntut untuk mampu : (1) mengadakan prediksi masa depan sekolah, misalnya tentang kualitas yang diinginkan masyarakat, (2) melakukan inovasi dengan mengambil inisiatif dan kegiatan-kegiatan yang kreatif untuk kemajuan sekolah, (3) menciptakan strategi atau kebijakan untuk mensukseskan pikiran-pikiran yang inovatif tersebut, (4) menyusun perencanaan, baik perencanaan strategis maupun perencanaan operasional, (5) menemukan sumbersumber pendidikan dan menyediakan fasilitas pendidikan, (6) melakukan pengendalian atau kontrol terhadap pelaksanaan pendidikan dan hasilnya.

b) Pemimpin Sekolah

Menurut Lipoto (1988) peranan kepemimpinan kepala sekolah adalah sebagai: (1) figurehead (symbol); (2) leader (memimpin; (3) liason (antara); (4) monitor (memonitor); (5) disseminator (menyebarkan) informasi; (6) spokesmen (juru bicara); (7) entrepreneur ( wiraswasta); (8) disturbance handler ( menangani gangguan); (9) resource allocator $e$ (pengumpul dana); (j) negotiator ( perunding). 
Lebih lanjut Lipoto (1988) mengatakan bahwa sebagai pemimpin, maka kepala sekolah harus mampu menggerakkan orang lain agar secara sadar dan sukarela melaksanakan kewajibannya secara baik sesuai dengan apa yang diharapkan pimpinan dalam mencapai tujuan. Kepemimpinan kepala sekolah terutama ditujukan kepada para guru karena merekalah yang terlibat secara langsung dalam proses pendidikan. Namun demikian, kepemimpinan kepala sekolah juga ditujukan kepada para tenaga kependidikan lainnya serta siswa.

Hal senada dikatakan Wahjosumidjo (2001), peran kepala sekolah sebagai pemimpin sekolah memiliki tanggung jawab menggerakkan seluruh sumberdaya yang ada di sekolah sehingga melahirkan etos kerja dan produktivitas yang tinggi dalam mencapai tujuan. Hick (dalam Wahjosumido, 2001) berpendapat bahwa untuk dapat menjadi pemimpin sekolah yang baik, kepala sekolah harus : (1) adil, (2) mampu memberikan sugesti (suggesting), (3) mendukung tercapainya tujuan (supplying objectives), (4) mampu sebagai katalisator, (5) menciptakan rasa aman (providing security), (6) dapat menjadi wakil organisasi (representing), (7) mampu menjadi sumber inspirasi (inspiring), bersedia menghargai (prising).

Dalam pelaksanaannya, keberhasilan kepemimpinan kepala sekolah, (Departemen Pendidikan Nasional, (2000) sangat dipengaruhi hal-hal sebagai berikut: (1) kepribadian yang kuat; kepala sekolah harus mengembangkan pribadi agar percaya diri, berani, bersemangat, murah hati, dan memiliki kepekaan sosial. (2) memahami tujuan pendidikan dengan baik; pemahaman yang baik merupakan bekal utama kepala sekolah agar dapat menjelaskan kepada guru, staf dan pihak lain serta menemukan strategi yang tepat untuk mencapainya. (3) pengetahuan yang luas; kepala sekolah harus memiliki pengalaman dan pengetahuan yang luas tentang bidang tugasnya maupun bidang yang lain yang terkait. (4) keterampilan professional yang terkait dengan tugasnya sebagai kepala sekolah, yaitu: (a) keterampilan teknis, misalnya: teknis menyusun jadwal pelajaran, memimpin rapat. (b) keterampilan hubungan kemanusiaan, misalnya : bekerjasama dengan orang lain, memotivasi, guru dan staf (c) keterampilan konseptual, misalnya mengembangkan konsep pengembangan sekolah, memperkirakan masalah yang akan muncul dan mencari pemecahannya.

Dalam masalah ini Wahjosumidjo (2001) berpendapat, bagi kepala sekolah yang ingin berhasil menggerakkan para guru/staf dan para siswa agar berperilaku dalam mencapai tujuan sekolah adalah: (1) menghindarkan diri dari sikap dan perbuatan yang bersifat memaksa atau bertindak keras terhadap guru, staf dan para siswa; (2) harus mampu melakukan perbuatan yang melahirkan kemauan untuk bekerja dengan penuh semangat dan percaya diri terhadap para guru, staf dan siswa, dengan cara meyakinkan dan membujuk. Meyakinkan (persuade) dilakukan dengan berusaha agar para guru, staf dan siswa percaya bahwa apa yang dilakukan adalah benar. Sedangkan membujuk (induce) adalah berusaha meyakinkan para guru, staf dan siswa bahwa apa yang dilakukan adalah benar. 
Pemimpin yang efektif selalu memanfaatkan kerjasama dengan para bawahan untuk mencapai cita-cita organisasi (Pidarta, 1990). Disamping itu menurut Mulyasa (2002), kepala sekolah yang efektif adalah kepala sekolah yang; (1) mampu memberdayakan guru-guru untuk melaksanakan proses pembelajaran dengan baik, lancar dan produktif; (2) dapat menyelesaikan tugas dan pekerjaan sesuai dengan waktu yang telah ditetapkan; (3) mampu menjalin hubungan yang harmonis dengan masyarakat sehingga dapat melibatkan mereka secara aktif dalam rangka mewujudkan tujuan sekolah dan pendidikan; (4) berhasil menerapkan prinsip kepemimpinan yang sesuai dengan tingkat kedewasaan guru dan pegawai lain di sekolah; (5) bekerja dengan tim manajemen; (6) berhasil mewujudkan tujuan sekolah secara produktif sesuai dengan ketentuan yang telah ditetapkan.

c) Administrator Sekolah

$\begin{array}{ccr}\text { Kepala } & \text { sekolah } & \text { sebagai } \\ \text { administrator } & \text { dalam } & \text { lembaga }\end{array}$ pendidikan mempunyai tugas-tugas antara lain : melakukan perencanaan, pengorganisasian, pengarahan, pengkoordinasian, pengawasan terhadap bidang-bidang seperti ; kurikulum, kesiswaan, kantor, kepegawaian, perlengkapan, keuangan, dan perpustakaan. Jadi kepala sekolah harus mampu melakukan; (1) pengelolaan pengajaran; (2) pengelolaan kepegawaian; (3) pengelolaan kesiswaan; (4) pengelolaan sarana dan prasarana; (5) pengelolaan keuangan dan; (6) pengelolaan hubungan sekolah dan masyarakat.

\section{d) Supervisor Sekolah}

Supervisi merupakan kegiatan membina dan dengan membantu pertumbuhan agar setiap orang mengalami peningkatan pribadi dan profesinya. Menurut Sahertian (2000), supervisi adalah usaha memberi layanan kepada guru-guru baik secara individual maupun secara berkelompok dalam usaha memperbaiki pengajaran dengan tujuan memberikan layanan dan bantuan untuk mengembangkan situasi belajar mengajar yang dilakukan guru di kelas.

Supervisi merupakan pengembangan dan perbaikan situasi belajar mengajar yang pada akhirnya perkembangan siswa. Itu perbaikan situasi belajar mengajar bertujuan untuk : (1) menciptakan, memperbaiki, dan memelihara organisasi kelas agar siswa dapat mengembangkan minat, bakat, dan kemampuan secara optimal, (2) menyeleksi fasilitas belajar yang tepat dengan problem dan situasi kelas, (3) mengkoordinasikan kemauan siswa mencapai tujuan pendidikan, (4) meningkatkan moral siswa.

Lebih lanjut Ngalim Purwanto (1987) mengemukakan bahwa supervisi ialah suatu aktivitas pembinaan yang diharapkan dapat meningkatkan kemampuan sekolah maupun guru, oleh karena itu program supervisi harus dilakukan oleh supervisor yang memiliki pengetahuan dan keterampilan mengadakan hubungan antar individu dan ketrampilan teknis. Supervisor di dalam tugasnya bukan saja mengandalkan pengalaman sebagai modal utama, tetapi harus diikuti atau diimbangi dengan jenjang pendidikan formal yang memadai.

Beberapa paparan di atas dapat disimpulkan bahwa kepala sekolah merupakan penyelenggara pendidikan yang juga, yaitu : (1) menjadi manajer lembaga pendidikan, (2) menjadi 
pemimpin, (3) sebagai penggerak lembaga pendidikan, (4) sebagai supervisor atau pengawas, (5) sebagai pencipta iklim bekerja dan belajar yang kondusif. Sesuai dengan peran dan tugastugas di atas, kepala sekolah sebagai manajer sekolah dituntut untuk dapat menciptakan manajemen sekolah yang efektif. Menurut Mantja (2000), keefektifan manajemen pendidikan ditentukan oleh profesionalisme manajer pendidikan. Adapun sebagai manajer terdepan kepala sekolah merupakan figur kunci dalam mendorong perkembangan dan kemajuan sekolah. Kepala sekolah tidak hanya meningkatkan tanggung jawab dan otoritasnya dalam programprogram sekolah, kurikulum dan keputusan personil, tetapi juga memiliki tanggung jawab untuk meningkatkan akuntabilitas keberhasilan siswa dan programnya. Kepala sekolah harus pandai memimpin kelompok dan mampu melakukan pendelegasian tugas dan wewenang (Nur Kholis, 2003).

Menurut Wohlstetter dan Mohrman (Dalam Nur Kholis, 2003) peran kepala sekolah dalam mbs adalah sebagai designer, motivator, fasilitator, dan liaison. Sebagai designer kepala sekolah harus membuat rencana dengan memberikan kesempatan untuk terciptanya diskusi-diskusi menyangkut isu-isu dan permasalahan di seputar sekolah dengan tim pengambil keputusan sekolah. Tentu saja dalam hal ini harus melibatkan berbagai komponen terkait secara demokratis.

3. Keterampilan Manajerial Yang Mendukung Keektifan Peran Kepala Sekolah

Agar dapat mencapai ketepatan sasaran dalam proses pengelolaan sumbersumber pendidikan, kepala sekolah harus mempunyai keterampilan manajemen umum (Scheerens and Bosker, 2001) antara lain: 1) keterampilan berpikir, 2) keterampilan menyediakan informasi, 3) keterampilan pembuatan keputusan yang partisipatif, 4) keterampilan mengkoordinasi.

1) Keterampilan berpikir kepala sekolah meliputi:

a. Kepala sekolah mempunyai pandangan yang jelas tentang bagaimana sekolah harus dikelola.

b. Kepala sekolah menyediakan kepemimpinan yang jelas dan tidak ambigus.

c. Kepala sekolah tahu kapan bertindak sebagai pemimpin

d. Kepala sekolah mempunyai kebijakan yang telah dipertimbangkan.

2) Keterampilan menyediakan informasi meliputi:

a. Tingkat ketepatan waktu dan kualitas informasi yang tersedia.

b. Penyampaian informasi secara teratur kepada orang tua siswa dan kepada komite sekolah.

c. Menyalurkan informasi sehingga dapat menjangkau orang- orang yang merasa dirinya terlibat.

d. Kepala sekolah menjamin bahwa ada informasi yang cukup kepada teman sejawat agar koordinasi tugas dapat terjangkau.

e. Kepala sekolah menyampaikan kepada staf pengajar tentang keputusankeputusan komite.

3) Keterampilan pembuatan keputusan yang partisipatif kepala sekolah meliputi

a. Kepala sekolah melibatkan orang tua siswa dalam pembuatan keputusan.

b. Kepala sekolah menjamin bahwa keputusan yang telah diambil bisa dilaksanakan.

c. Kepala sekolah menjamin bahwa keputusan yang jelas dibuat dalam rapat.

d. Kepala sekolah merasa bahwa pelibatan guru dalam pembuatan keputusan merangsang keefektifan sekolah.

e. Kepala sekolah melibatkan guru 
dalam pembuatan keputusan tentang penyesuaian guru dan bidang studi, penyediaan bahan dan alat bantu mengajar dan pengembangan sekolah.

4) Keterampilan mengkoordinasi kepala sekolah meliputi:

a. Kepala sekolah bertindak sebagai penggagas inisiatif dari setiap rapat.

Atmodiwirio, $\quad \mathrm{S}$

mengemukakan bahwa kepala sekolah sebagai manajer lebih menonjol jika dibandingkan dengan peran sebagai pemimpin pengajaran, untuk menjadi seorang kepala sekolah yang efektif diperlukan adanya lima keterampilan adaministrasi dan kompetensi yakni:

a. Keterampilan teknis, meliputi pengetahuan khusus dan keahlian pada suatu kegiatan khusus yang bertalian dengan fasilitas, yaitu dalam cara penggunaan alat dan teknik pelaksanaan kegiatan.

b. Keterampilan hubungan manusia, berkaitan dengan kerja sama dengan orang lain, kemampuan untuk memberikan bantuan dan bekerja sama dengan orang lain maupun kelompok untuk mencapai tujuan oranganisasi.

c. Keterampilan membuat konsep, kemampuan untuk merangkum menjadi satu dalam bentuk gagasan atau ide-ide melihat organisasi sebagai suatu keseluruhan situasi yang relevan dengan organisasi itu. D. Keterampilan pendidikan dan pengajaran, meliputi penguasaan pengetahuan tentang belajar mengajar.

d. Keterampilan kognitif, meliputi kemampuan dan pengetahuan yang bersifat intelektual.

Menurut Wahjosumidjo (1999)

kunci keberhasilan suatu sekolah pada hakekatnya terletak pada efisiensi dan efektivitas penampilan kepala sekolah. Oleh karena itu kualitas kepemimpinan kepala sekolah perlu ditingkatkan dengan menekankan pengembangan tiga keterampilan dasar, yaitu: 1) conceptual skill $i$ keterampilan membuat konsep, 2) human skill / keterampilan hubungan manusia, 3) technical skill / keterampilan teknis. Dengan memiliki tiga keterampilan dasar ini, kepala sekolah diharapkan mampu dalam hal: menentukan tujuan sekolah, mengorganisasi atau mengatur sekolah, menanamkan pengaruh atau kewibawaan kepemimpinannya, memperbaiki pengambilan keputusan, dan melaksanakan perbaikan pendidikan.

Kepala sekolah bertugas sebagai administrator, supervisor dan pemimpin. Dalam kaitan ini tugas kepala sekolah adalah merencanakan, mengorganisasikan, melaksanakan, dan mengawasi pelaksanaan kegiatan pada setiap substansi administrasi sekolah, sebagai supervisor kepala sekolah bertugas melaksanakan fungsi pembinaan professional terhadap guru-guru agar dapat melaksanakan pembelajaran secara efektif. Selanjutnya sebagai pemimpin tugas kepala sekolah adalah mempengaruhi, menggerakkan, mengarahkan dan mengendalikan guru-guru agar tugas-tugas yang dilaksanakan terarah kepada pencapaian tujuan pendidikan. Dengan demikian, seorang kepala sekolah seyogyanya memiliki beberapa keterampilan manajemen .

Keterampilan-keterampilan manajemen yang dibutuhkan oleh seorang manajer yang efektif termasuk kepala sekolah menurut Handoko (2000) Adalah sebagai berikut:

1) Keterampilan konseptual (conceptual skills) adalah kemampuan mental untuk mengkoordinasikan dan mengintegrasikan seluruh kepentingan dan kegiatan organisasi. Keterampilan ini mencakup kemampuan manajer untuk melihat organisasi sebagai suatu keseluruhan dan memahami hubungan antar bagian yang saling bergantung serta mendapat, menganalisa dan menginterpretasikan informasi yang diterima dari bermacam-macam 
sumber.

2) Keterampilan kemanusiaan (human skills) adalah kemampuan untuk bekerja dengan memahami dan memotivasi orang lain baik sebagai individu maupun kelompok. Seorang manajer membutuhkan keterampilan ini agar dapat memperoleh partisipasi dan mengarahkan kelompoknya dalam pencapaian tujuan.

3) Keterampilan administratif (administrative skills) adalah seluruh keterampilan yang berkaitan dengan perencanaan, pengorganisasian, penyusunan kepegawaian dan pengawasan. Keterampilan ini mencakup kemampuan untuk mengikuti kebijaksanaan dan prosedur, mengelola dengan anggaran terbatas, dan sebagainya.

4) Keterampilan teknis (technical skills) adalah kemampuan untuk menggunakan peralatan-peralatan, prosedur-prosedur, atau teknik-teknik dari suatu bidang tertentu.

Dari beberapa pendapat pakar tersebut diatas dapat dipahami bahwa untuk meningkatkan kualitas organisasi sekolah maka kepala sekolah hendaklah seseorang yang memiliki visi dan misi kelembagaan, memiliki kemampuan konseptual, memiliki keterampilan dan seni dalam hubungan antar manusia, menguasai aspek-aspek teknis dan substantif pekerjaannya, memiliki semangat untuk maju, serta memiliki semangat mengabdi dan karakter yang dapat diterima oleh lingkungannya.

\section{PENINGKATAN KINERJA GURU}

\section{Pengertian Kinerja}

Istilah kinerja mengambil istilah performansi yang memiliki beberapa kata lain. Menurut manajemen istilah performansi atau disebut dengan kinerja. Kinerja dapat berupa proses dan hasil kerja secara individu maupun organisasi.
Hal ini berguna bagi pengukuran efektifitas pencapaian tujuan dan pelaksanaan rencana. Menurut Longenecker Dan Pringel (1981), mengemukakan bahwa pengendalian kinerja berarti pemantauan organisasi terhadap penetapan tujuan dan pelaksanaan rencana ini relatif tergantung pada Sumber Daya Manusia (SDM) dalam organisasi. Dengan demikian kinerja dapat berupa kemampuan individu dalam melaksanakan tujuan dan rencana menurut standart tertentu. Selanjutnya Bernandin \& Russel (1993) memberi batasan mengenai kinerja sebagai catatan yang dihasilkan dari fungsi suatu pekerjaan tertentu atau kegiatan selama suatu periode waktu tertentu. Menurut Maier (1965), kinerja diberi batasan sebagai kesuksesan seseorang dalam melakukan pekerjaannya. Dalam kamus besar bahasa indonesia diartikan kinerja sebagai prestasi yang diperlihatkan kemampuan kerja (Depdikbud, 1997). Juga dalam encyclopedia of psychology disebutkan bahwa kinerja diartikan sebagai tingkah laku, keterampilan, atau kemampuan seseorang dalam menyelesaikan suatu kegiatan (Eynck, Wurburg \& Meili, 1972).

Selanjutnya pengertian kinerja dapat disamakan dengan "performance", sebagaimana dikemukakan oleh Prawirosentono, (1999) bahwa kinerja adalah hasil kerja yang dapat dicapai oleh seseorang atau sekelompok orang dalam suatu organisasi, sesuai dengan wewenang dan tanggungjawab masingmasing, dalam rangka upaya mencapai tujuan organisasi yang bersangkutan secara legal, tidak melanggar hukum dan sesuai dengan moral maupun etika.

Smith (1976) mengkaitkan kinerja dengan tujuan organisasi. Menurutnya pengertian kinerja berhubungan dengan tugas aspek pokok, yaitu : perilaku, hasil, dan efektifitas organisasi. Sedangkan Bernandian \& Russel (1993) memberikan 
batasan mengenai kinerja sebagai catatan outcome yang dihasilkan dari fungsi dari fungsi suatu pekerjaan tertentu atau kegiatan selama periode waktu tertentu. Selanjutnya pengertian tersebut dilengkapi oleh Byars dan Rue (1991), selain berkenaan dengan tingkat pencapaian dari tugas-tugas yang menjadi pekerjaan seseorang, juga hal tersebut merefleksikan seberapa baik seseorang tersebut memenuhi syarat-syarat dari sebuah pekerjaan.

Jadi kinerja adalah perilaku menunjukkan pada kegiatan dalam mencapai tujuan. Sementara hasil menunjukkan pada efektifitas perilaku individu, baik bersifat individu, baik bersifat obyektif maupun subyektif, sedangkan efektifitas organisasi merupakan langkah-langkah dalam pertimbangan hasil kerja organisasi yang menekankan pada aspek-aspek proses

\section{Kinerja Guru}

Guru mempunyai peranan yang sangat penting dalam mencapai kualitas pendidikan. Upaya yang strategis dalam mencipkan guru yang berkualitas adalah memberi layanan secara terus menurus kepada guru sehingga kinerja guru meningkat. Sedangkan kinerja guru tidak terlepas dari tugas yang harus diemban guru itu sendiri. Dalam melaksanakan tugasnya guru juga harus mampu memberikan layanan dan membangkitkan semangat untuk berprsetasi di antara siswa. Tugas ini tidak ringan bagi kalangan guru karena karakteristik yang melekat pada pekerjaan guru itu sendiri. Karakteristik tersebut sebagaimana yang diungkapkan oleh Zamroni (2000) Adalah ;

a) Pekerjaan guru bersifat individual dan cenderung noncollaborative.

b) Pekerjaan guru dilakukan di ruang-ruang kelas yang terisolir dalam jangka waktu yang lama. c) Waktu guru untuk berdialog akadenik dengan sesama guru sangat terbatas.

Senada dengan pendapat Doyle dalam Kyle (1985) menyatakan apa yang dipelajari siswa selama di sekolah banyak bergantung pada apa yang terjadi di kelas dan apa yang terjadi di kelas tergantung pada bagai prakarsa guru untuk mengimplementasikan kurikulum ke dalam kegiatan belajar di kelas.

Dengan demikian peranan guru sangatlah penting dalam mencapai keberhasilan pembelajaran. Maka dapat digambarkan guru yang dapat bekerja secara efektif adalah sebagai berikut : 1) mampu menjaga kelangsungan interaksi yang aktif dan memfokuskan pada bahan pelajaran yang diwujudkan dengan adanya organisasi dan manajemen kelas yang baik, 2) memberi tugas yang jelas, menerapkan langkah pembelajaran yang cepat dengan tetap mengarah pada pencapaian hasil, 3) melakukan monitoring tiap kemajuan yang harus di capai.

Kinerja guru sangat terkait dengan efektifitas guru dalam melaksanakan fungsinya. Keefektifan guru dalam melaksanakan fungsinya. Keefektifan guru dalam melaksanakan fungsinya oleh Medley dalam Depdikbud (1984), dijelaskan bahwa efektifitas guru adalah : 1) guru yang efektif adalah mereka yang memiliki pribadi kooperatif, daya tarik penampilan, minat besar, pertimbangan dan kepemimpinan, 2) guru yang efektif adalah mereka yang menguasai metode mengajar yang baik, 3) guru yang efektif adalah mereka memiliki tingkah laku yang baik saat mengajar, 4) guru yang efektif adalah guru yang menguasai berbagai kompetensi dalam mengajar.

Dengan demikian guru yang efektif harus memiliki kompetensi yang disyaratkan untuk menjalankan tugasnya dalam mengemban mencerdaskan kehidupan bangsa. Menurut Raka Joni, T 
dalam bukunya Suharsimi Arikunto (1993) bahwa ada tiga kompetensi guru yang harus ada pada diri guru yaitu sebagai berikut : 1) kompetensi profesional, artinya guru harus memiliki pengetahuan yang luas serta dalam tentang subyek matter yang akan diajarkan serta penguasaan metodologi pengajaran, 2) kompetensi personal, artinya guru harus memiliki sikap kepribadian yang mantap, sehingga mampu menjadi sumber intensifikasi bagi subyek didik, 3) kompetensi sosial, artinya guru harus memiliki kemampuan berkomunikasi sosial, baik dengan muridmuridnya maupun dengan sesama tema guru, dengan kepala sekolah dengan pegawai tata usaha, dan anggota masyarakat lingkungannya.

\section{INDIKATOR KEEFEKTIFAN DAN KINERJA GURU}

\section{Indikator Keefektifan}

Pekerjaan seseorang dikatakan efektif jika dapat memberikan hasil yang sesuai dengan kinerja yang ditetapkan atau sudah mampu mewujudkan tujuan organisasi dalam aspek yang dikerjakan tersebut. Pada hakekatnya keefektifan organisasi bukanlah keefektifan pribadi melainkan keefektifan manajer dan manajer yang efektif akan menghasilkan manajemen yang efektif, kriteria kepala sekolah yang efektif dapat dilihat dari kemampuannya dalam mengkreasikan alternatif-alternatif, mengoptimalkan sumber belajar dan meningkatkan keuntungan sekolah.

Engkoswara (Dalam Mulyasa, 2002) mengatakan bahwa keberhasilan manajemen pendidikan adalah produktivitas pendidikan yang dilihat pada prestasi atau keefektifan pada efisiensi. Aspek keefektifan dapat dilihat pada masukan yang merata, keluaran yang banyak dan bermutu tinggi.
Depdikbud (1988) mengidentifikasi keefektifan sekolah dalam kelompok keefektifan internal dan keefektifan eksternal. Keefektifan internal menunjukkan pada keluaran pendidikan yang tidak diukur secara moneter seperti prestasi belajar dan jumlah lulusan, adapun keefektifan eksternal menunjuk pada keluaran yang bersifat moneter seperti tingkat penghasilan lulusan.

Hoy Dan Miskel mengatakan bahwa keefektifan organisasi adalah suatu fenomena multidimensional yang terdiri atas komponen-komponen adaptasi dari kuantitas dan kualitas dari produk, pencapaian hasil belajar siswa yang tinggi, sistem tujuan yang terintegrasi dan kesamaan yang dapat menuntun penyelesaian terhadap indikator-indikator keefektifan. Indikator keefektifan dalam pandangan miskel dan hoy meliputi: basil/output, moral organisasi, dan keuntungan organisasi.

Admonds (Dalam Sagala, 2005) menunjuk lima indikator keefektifan organisasi sekolah, yaitu: (1) harapanharapan yang tinggi dari keefektifan pengajaran, (2) kepemimpinan instruksional yang kuat oleh kepala sekolah, (3) iklim yang teratur, tenang dan berorientasi kerja sekolah, (4) melaksanakan kegiatan akademik, dan (5) pemantauan atas kemajuan siswa. Indikator keefektifan meliputi:

a) Indikator input: meliputi karakteristik guru, fasilitas, perlengkapan, dan mated pendidikan serta kapasitas manajemen

b) Indikator proses: meliputi prilaku administratif, alokasi waktu guru, dan alokasi waktu anak didik

c) Indikator output: meliputi hasil- hasil dalam bentuk perolehan anak didik dan dinamika sistem sekolah, hasil- hasil yang berkaitan dengan prestasi belajar, serta hasil-hasil yang berkaitan dengan keadilan dan kesamaan

d) Indikator outcome: meliputi pekerjaan 
serta pendapatan setelah lulus

Dari uraian dan pendapat beberapa Pakar tersebut di atas apabila dikaitkan dengan keefektifan kepala sekolah dan penerapan fungsi-fungsi manajemen, maka indikator keefektifan dapat dilihat dari kualitas program, ketepatan penyusunan program, semangat kerja, ketepatan waktu, ketepatan pendayagunaan sarana dan prasarana, tercapainya tujuan, dan sumber belajar dalam meningkatkan kualitas pendidikan di sekolah.

\section{Indikator Kinerja Guru}

Untuk mencapai keberhasilan sekolah atau sekolah yang efektif maka kinerja guru harus benar-benar di diukur dan kontrol dengan baik. Proses untuk menilai kinerja pegawai disebut penilaian kinerja. Dikatakan demikian karena penilaian kinerja mencoba memberikan kepada pegawai sebuah umpan balik. Karena mereka membutuhkan untuk berkembang, tanpa mengurangi kebebasan dan motivasi untuk melakukan pekerjaan dengan baik.

Windham (1990) mengemukakan tentang penilaian kinerja guru yaitu kegiatan belajar mengajar dan pemanfaatan waktu guru di sekolah. Kegiatan belajar mengajar mencakup kegiatan perencanaan pengajaran, proses belajar mengajar, evaluasi dan pemantauan, dan kegiatan administratif. Dari segi pemanfaatan waktu guru di sekolah merupakan kegiatan pengalokasian waktu di sekolah sebagai guru.

Selanjutnya Medley, Coker dan Soar (1984) mengemukakan bahwa penilaian kinerja guru difokuskan pada tindakan pengajaran dan dirancang untuk menilai kualitas pengajaran. Dimensi penilaian dapat dipilih melalui tiga pola strategi, yaitu strategi teoritik (teori pengajaran), strategi konsensus tentang guru yang efektif, dan pemanfaatan hasilhasil penelitian. Teori pengajaran menunjuk pada perumusan persiapan pengajaran, penciptaan serta pemeliharaan lingkungan belajar yang menyenangkan, penerapan pengajaran, dan individualisasi. Pendekatan konsesnsus dengan meminta opini beberapa kelompok guru secara terbatas mengenai pandangan pengajaran yang efektif. Guru harus memiliki kemampuan profesional yang tinggi dan memiliki kemampuan profesional yang tinggi dan memiliki peran yang tangguh sebagai fasilisator belajar, seorang motivator belajar, dan seorang pengelola proses belajar mengajar. Jika status dan peran tersebut benar-benar dimiliki dan dimainkan oleh guru di dalam situasi pendidikan, maka tujuan untuk meningkatkan mutu pendidikanakan lebih cepat menjadi kenyataan.

Selanjutnya Mulyasa (2002) mengemukakan bahwa seorang guru dikatakan berhasil mengelolah kelas, apabila memenuhi indkator-indikator sebagai berikut : 1) menguasai dan memahami bahan dan hubungannya dengan bahan lain secara baik, 2) menyukai apa yang diajarkannya dan menyukai mengajar sebagai sebuah profesi, 3) memahami peserta didik, pengalaman, kemampuan dan prestasinya, 4) menggunakan metode yang bervariasi dalam mengajar, 5) mampu mengeliminasi bahan-bahan yang kurang penting dan kurang berarti, 6) selalu mengikuti perkembangan pengetahuan yang mutakhir, 7) proses pembelajaran selalu dipersiapkan, 8) mendorong peserta didiknya untuk memperoleh hasil yang lebih baik, dan 9) menghubungkan pengalaman yang lalu dengan bahan yang akan diajarkan.

Dari pandangan tersebut diatas dapat disimpulkan bahwa indikator kinerja guru adalah sebagai berikut ; 
a. Perwujudan kepribadian yang baik di dalam maupun di luar sekolah.

b. Melaksanakan kegiatan belajar mengajar, termasuk didalamnya kegiatan membuat rencana mengajar, melaksanakan pengajaran, menggunakan metodologi mengajar, hubungan antar pribadi, monitoring, dan evaluasi hasil belajar.

c. Menggunakan waktu luang guru di dalam maupun di luar sekolah.

d. Mengembangkan profesi guru.

e. Pengorganisasian siswa dan kelas serta bahan belajar.

f. Kecakapan berkomunikasi dengan siswa.

g. Simpati dan empati pada orang lain, khususnya siswa dalam hubungannya dengan kegiatan belajar mengajar.

Untuk kepentingan disini penetapan ukuran kinerja guru menggunakan ukuran kegiatan belajar mengajar dan alokasi waktu dalam melakukan kegiatan sebagai guru di sekolah. Kegiatan belajar mengajar guru dibatasi pada kegiatan perencanaan pengajaran, proses belajar mengajar, pemantauan dan evaluasi, kegaiatan administrasi. Segi pemanfaatan waktu guru di sekolah dimaksudkan sebagai aktivitas sehari-hari dalam mengalokasikan waktunya di sekolah. Alokasi waktu di sekolah meliputi kegiatan administratif, pengajaran, pemantauan dan evaluasi, dan pengembangan diri. Yang semuanya itu sebagai perwujudan dari kinerja guru.

\section{DAFTAR PUSTAKA}

Atmodiwirio, Soebagio. 2000. Manajemen Pendidikan Indonesia. Ardadizya. Jakarta

Depdiknas RI. 2013. Undang-Undang No. 20 Tahun 2003 Tentang Sistem Pendidikan Nasional Citra Umbara. Bandung
Efendi, A.R. 1997. Dasar-Dasar Manajemen Pendidikan Untuk Peningkatan Kualitas Sekolah Dasar. Malang: IKIP Malang

Effendi, A.R. 1997. Dasar-Dasar Manajemen Pendidikan Untuk Meningkatkan Kualitas Sekolah Dasar. IKIP University Press. Malang

Fatah, N. 1996. Landasan Manajemen Pendidikan. PT Remaja Rosda Karya. Bandung

Mantja, W. 2002. Manajemen Pendidikan Dan Supervisi Pengajaran. Malang: Wineka Media Menyukseskan MBS Dan KBK. PT Remaja Rosda Karya. Bandung

Mulyasa. 2003. Menjadi Kepala Sekolah Profesional Dalam Konteks. Remaja Karya.Bandung

Nawawi, H. 1995. Kepemimpinan Efektif. Gajahmada University Press. Jogyakarta.

Pidarta, Made. I. 1990. Perencanaan Pendidikan Dengan Pendekatan Sistem. Rineka Cipta. Jakarta

Purwanto, Ngalim. 2003. Administrasi Dan Supervisi Pendidikan. PT Remaja Rosda Karya. Bandung

Sagala, S. 2005. Manajemen Berbasis Sekolah Dan Masyarakat, Strategi Memenangkan Persaingan Mutu. PT. Mimas Multima. Jakarta

Supriyono, R. 2000. Sistem Pengendalian Manajemen. BPFE. Yogyakarta

Suryosubroto, B. 2004. Manajemen Pendidikan Di Sekolah. Rineka Cipta. Jakarta

Syafaruddin. 2002. Manajemen Mutu Terpadu, Konsep Strategi Dan Aplikasi. Gramedia Sarana Indonesia. Jakarta

Thoha, Miftah. 2000. Kepemimpinan Dalam Manajemen. Radja Grafindo Persada. Jakarta

Tilaar, H. A.R. 2001. Beberapa Agenda Reformasi Pendidikan Nasional. Indonesia Tera. Jakarta

Uno, Hamzah. 2006. Perencanaan Pembelajaran. Bumi Aksara. Jakarta

Wahjosumidjo. 1999. Kepemimpinan Kepala Sekolah, Tinjauan Teoritik Dan Permasalahannya. Jakarta: PT. Raja Grafindo Persada. 